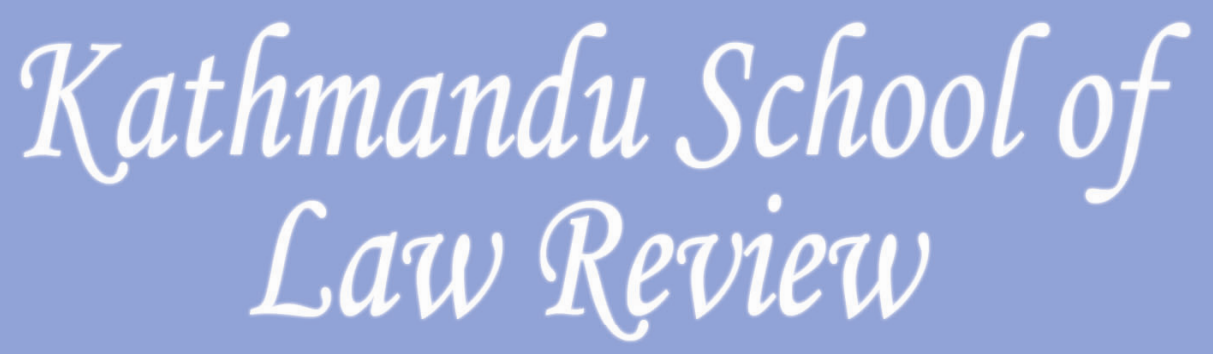

ISSN 2091-2110

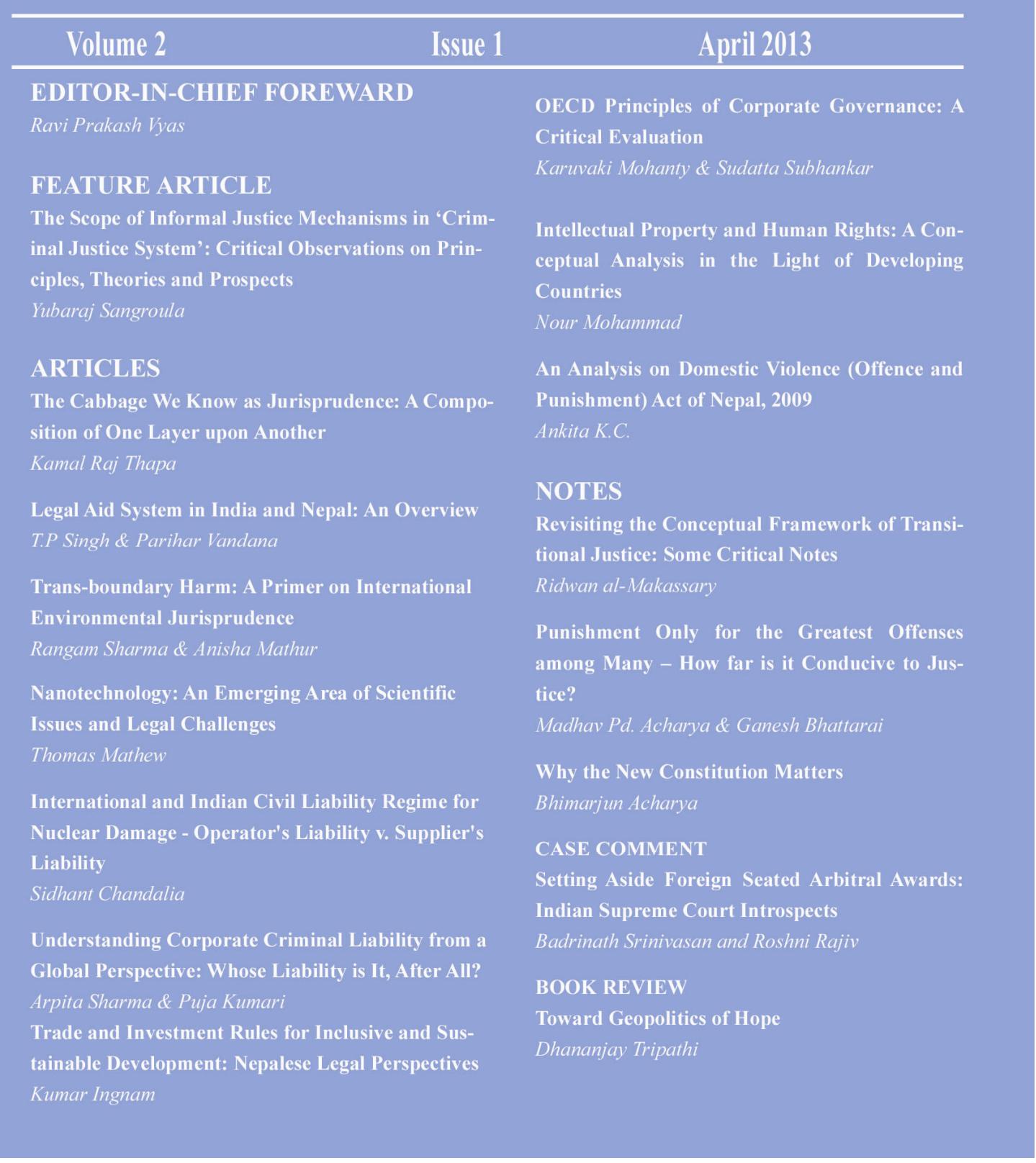




\title{
Understanding Corporate Criminal Liability from a Global Perspective: Whose Liability is It, After All?
}

\author{
Arpita Sharma $^{1}$ \& Puja Kumari ${ }^{2}$
}

\begin{abstract}
The jurisprudential foundations of the Criminal Liability of Corporations were laid down much lately in countries like France and India as compared to USA and United Kingdom. This article is a modest attempt on the part of the authors to revisit the subject matter of corporate criminal liability which is often dealt within legal literature as just another offence under the Indian Criminal Justice System. It thoroughly tracks the legislative developments since the origination of the concept in the Romanic Law in $12^{\text {th }}-14^{\text {th }}$ century till date, along with the provisions laid down and emergence of the concept in different part of the world. Judicial moods in interpretations to provisions pertaining to corporate criminal liability have been unearthed to show a conservative judiciary giving way to a liberal one, loosening the shackles of power. Laws on the corporate criminal liability need major changes-from amendments in laws to changes in judicial interpretations to changes in victim treatment and approach. This paper attempts to expound the complete subject matter in a thought-through manner to reawaken thinking of an improvised and transformed system of law. A steep rise in the number of crimes committed by the corporations clearly reveals a prima facie malfunctioning of corporate governance which, in return, calls for a much more efficient enforcement of law.
\end{abstract}

\section{Forward: The Changing Dimension of Corporate Criminal Liability and Comparative Analysis}

'I'm Lingley of Lingley Ltd. Not one of you can touch me. I turned myself into a company years ago.' -Sutton Vane, Outward Bound.

Considerable debate environs society's increasing reliance on criminal liability to control corporate activities, some have even interrogated in depth the fundamental foundation to

\footnotetext{
$1 \quad 2^{\text {nd }}$ Year student, B.A. LL.B. at College of Legal Studies, University of Petroleum \& Energy Studies, Dehradun, Uttarakhand, India.

$2 \quad 2^{\text {nd }}$ Year student, B.B.A. LL.B at College of Legal Studies, University of Petroleum \& Energy Studies, Dehradun, Uttarakhand, India.
} 
bring corporations within the purview of criminal liability ${ }^{3}$. The debate became particularly noteworthy following the 1990s, when both the United States and Europe confronted an alarming figure of environmental, antitrust, fraud, food and drug, false statements, worker death, bribery, obstruction of justice ${ }^{4}$, and financial crimes involving corporations. Corporate crimes result in severe losses. Magnificent monetary losses, deficiency of jobs and sometimes even loss of lives ${ }^{5}$ are the outcomes that most directly affect the general masses ${ }^{6}$. Simultaneously, the long-term effects of these crimes, such as the destructive upshot upon the environment or health, which may not sternly affect us now, should not be underrated $^{7}$. Although the imposition of criminal liability on corporations, in contrast to managers or employees, has generated cosmopolitan discussion ${ }^{8}$, commentators have not expansively examined why corporate criminal liability exists. After all, corporations cannot be imprisoned ${ }^{9}$. Moreover, it is not apparent that corporate criminal liability is the best way to influence corporate behaviour.

At present, most countries consent that corporations can be endorsed under civil and administrative laws. However, the criminal liability of corporations has been more contentious. While several jurisdictions have acknowledged and applied the concept of corporate criminal liability under different models, other law structures have not been able or willing to integrate it ${ }^{10}$. Critics have expressed strong opinions against its effectiveness and reliability with the principles of criminal law.

Out of all the countries, America has developed an extensive system of corporate criminal liability till now. American model comprises a very vast variety of criminal sanctions for corporations which strictly include fines ${ }^{11}$, corporate probation, order of negative publicity, etc. in an effort to effectively punish and charge corporations when any employee or worker commits an offense while acting within the capacity of his or her service and on behalf of

3 Pamela H. Bucy, 'Corporate Criminal Liability: When Does It Make Sense?' (2009) 46 American Criminal Law Review,1437; See also Pamela H. Bucy, 'Corporate Ethos: A Standard for Imposing Corporate Criminal Liability’ (1991) 75 Minnesota Law Review, 1095.

$4 \quad$ Arthur Andersen LLP v. U.S., 544 SC 696 (the US, 2005).

5 David Barstow \& Lowell Bergman, 'Deaths on the Job, Slaps on the Wrist', New York Times (the US, 10 January 2003).

6 Albert W. Alschuler, 'Two Ways to Think About the Punishment of Corporations' (2009) 46 American Criminal Law Review, 1359.

7 Amihud\& Lev, 'Risk Reduction as a Managerial Motive for Conglomerate Mergers' (1981) 12 Bell Journal of Economics, 605.

8 Richard A. Posner, Economic Analysis Of Law (4 $4^{\text {th }}$ edn, Little, Brown and Company 1992); Barry B. Baysinger, 'Organization Theory and the Criminal Liability of Organizations' (1991) 71 B.U. L. Rev, 341.

9 Bucy (n 3).

10 Ellen S. Podgor, 'A New Corporate World Mandates a Good Faith Affirmative Defense' (2007) 44 American Criminal Law Review, 1537.

11 Brent Fisse \& John Braithwaite, 'The Allocation of Responsibility for Corporate Crime: Individualism, Collectivism and Accountability' (1988) 11 Sydney Law Review, 468. 
the corporations ${ }^{12}$.The Penal Code 1994 introduced the concept of corporate criminal liability in French law. Initially applicable to a limited number of offences, the principle has been extended to all offences as of 31 December 2005. In the UK, the theory of 'identification' is followed to deal with the corporate criminal liability. The doctrine has its foundation in the landmark case of Lennard's Carrying Co Ltd v Asiatic Petroleum Co $L t d^{13}$, in which it was observed that 'A corporation is an abstraction ... its active mind and directing will must consequently be sought in the person ... who is really ... the very ego and centre of the personality of the corporation.'

In the era of 1940 there was a gradual shift from the principle of vicarious liability mainly to find that the corporations can be made directly liable for the acts of its employees.

The criminal liability of corporations does not exist in Germany. Instead, Germany opted for a comprehensive administrative-penal system which controls the misconduct of corporate criminals $^{14}$.

Now when it comes to India, the law was unenthusiastic to impose criminal liability on the corporations for quite a long time even though there were thousands of scandals which included the white collar crimes and the organized crimes. The main reason behind such reluctance was the laws in the statutes do not recognize the criminal liability of the corporation since the corporations cannot be imprisoned and there are a lot of crimes defined in Indian Penal Code which does not impose fine as a punishment and only imprisonment as a mode of punishment. The concept of the corporate criminal liability came into existence only after the case of Standard Chartered Bank et al. v. Directorate of Enforcement et $a l^{15}$, wherein the Supreme Court held that the criminal liability on corporation can be imposed and in this case the criminal liability was imposed on the company by imposing fine on the corporation. This concept arose right after the case of The Assistant Commissioner, Assessment- II, Bangalore et al. v. Velliappa Textiles Ltd. et al. ${ }^{16}$, in which B.N. Srikrishna J.asserted that corporate criminal liability cannot be imposed without making corresponding legislative changes.

In Nepal, corporate criminal liability is not fully recognized ${ }^{17}$. Few provisions of the companies Act and PC Act provide for making the principal officials and directors of company liable for the commission of crimes. But the company is not held liable directly

\footnotetext{
12 Posner (n 8).

13 Lennard's Carrying Co Ltd v Asiatic Petroleum Co Ltd [1915] AC 705.

14 Peter J. Henning, 'Corporate Criminal Liability and the Potential for Rehabilitation' (2009) 46 American Criminal Law Review, 1417.

15 Standard Chartered Bank et al. v. Directorate of Enforcement et al AIR 2005 SC, 2622 (India).

16 The Assistant Commissioner, Assessment- II, Bangalore et al .v. Velliappa Textiles Ltd. et al AIR 2004 SC 86 (India).

17 Binaya Sigdel, 'Pinning Responsibility', Republica (Kathmandu, 02 August 2012), <http://www.myrepublica.com/portal/index.php?action=news_details\&news_id=38970> accessed 10 April 2013.
} 
for the commission of any crime. In countries like Nepal, the concept of secondary liability is followed according to which if a crime is committed by any corporation or companies then it is not the company that is held liable but the principal officials who are in the position of taking decisions for the company.

\section{Chronological Advancement}

From $12^{\text {th }}$ to $14^{\text {th }}$ centuries, the concept of corporate criminal liability originated; the Romanic Law clearly imposed criminal liability on the universitas ${ }^{18}$, but only when its members were functioning together ${ }^{19}$. Simultaneously, Pope Innocent IV shaped the foundation for the maxim societasdelinquere non potest by stating that, unlike folks who have determination and aspirit, can obtain the unity, and are the issues of God's and emperor's penalties; universitas are fictions deficient in a body and a soul, and as a result, cannot be penalized. The Kings and popes often used to endorse ${ }^{20}$ the villages, provinces, and corporations.

In France, Ordonnance de Blois ${ }^{21}$ of 1579 enacted the criminal liability of corporations. Criminal liability of corporations originated in ancient law and became the centre of doctrinal dialogue at the end of the 19th century. In the early sixteenth and seventeenth centuries, it was generally believed that corporations could not be held criminally liable.

The chronological advancement of corporate criminal liability exposes that corporate criminal liability is part of an important 'public policy'22 bargain. The bargain balances the rights permitted upon the lawful recognition of a corporation, like limited liability of corporate shareholders, with law conformity and crime deterrent pressures on the managers of the consequential corporate entity., 23

France's instance was pursued by various other European countries. Consequently, Belgium, through the Law of 4 May 1999, modified article 5 of the Belgian Penal Code and introduced the criminal liability of juristic person ${ }^{24}$. Netherland spotted for the notion of corporate criminal liability even earlier in 1976. Article 51 of the Dutch Penal Code says that natural persons as well as juristic persons can commit crimes. In 2002, Denmark

18 Universitas comprised of the Roman state and other entities with religious, administrative, financial, or economic scopes.

19 Florin Streteanu \& RaduChiriță, Răspundereapenală a persoaneijuridice (2 ${ }^{\text {nd }}$ edn , C.H. Beck Publishing. House 2007) 72.

20 The endorsements forced could be fines, the loss of definite rights, termination and religious endorsements upon the members of the corporations.

21 According to which the offense done must have been the outcome of a collective verdict was made an essential element for the corporate criminal liability.

22 John C. Coffee Jr. 'No Soul to Damn: No Body to Kick: An Unscandalized Inquiry into the Problem of Corporate Punishment' (1981) 79 Michigan Law Review, 386.

23 'Corporations Face Stiffer Sentencing: Panel Gets Tough on Lawbreakers' The Washington Post (the USA, 8 November 1989).

24 Streteanu \& Chirita (n 19). 
modified its Penal Code and established that corporations may be liable for all offenses within the general criminal code ${ }^{25}$. Germany in contrast, because of doctrinal concerns, still refuses to go along with the idea of incorporating corporate criminal liability in its legal system $^{26}$ rather the liability of corporations are regulated mainly through administrative and civil laws. Italy, Portugal, Greece, and Spain followed the model that rejected to hold corporation criminally liable ${ }^{27}$.

The idea of corporate criminal liability in India evolved only after the case of Standard Chartered Bank wherein the Apex court imposed the liability on the company by imposition of fine on the corporation. Even the Law Commission in its $41^{\text {st }}$ report suggested some necessary changes so as to smoothen the concept of corporate criminal liability. The issue of imposing criminal liability of corporation has snagged Indian courts, which for a long time were of the opinion that corporations cannot be held criminally liable for the offences of which mens rea is an essential component.

\section{Prerequisites of Corporate Criminal Liability:}

The majority of the debates regarding the corporate criminal liability are based on the opinion societasdelinquere non potest and on the attitude that the liability ${ }^{28}$ imposed on corporations for corporate crimes $^{29}$ is not sufficient. Some of the basic propositions in corporate criminal liability are:

- What entities can be held criminally liable?

- Corporations can be held criminally liable for which all crimes?

- When and which Natural Persons can attract corporate criminal liability?

- What are the criminal sanctions available for corporate crimes?

\section{What entities?}

A corporation can raise an action against the person who cause harm to it. It would be strange to admit that a corporation is an actuality when it is injured by others, but not when it infringes the rights of other persons ${ }^{30}$. So, the 'fictive character' argument cannot be

\footnotetext{
25 Sara Sun Beale \& Adam G. Safwat, 'What Developments in Western Europe Tell Us about American Critiques of Corporate Criminal Liability' (2004) 8 Buffalo Criminal Law Review 89.

26 Leonard Orland \& Charles Cachera, 'Corporate Crime and Punishment in France: Criminal Responsibility of Legal Entities (Personnes Morales) under the New French Criminal Code (Nouveau Code Pénal)' (1995) 11 Connecticut Journal of International Law, 111.

27 Gunter Heine, 'New Developments in Corporate Criminal Liability in Europe: Can Europeans Learn from the American Experience-or Vice Versa?' (1998) St. Louis-Warsaw Transatlantic Law Journal, 174.

28 Like civil or administrative liability of corporations or criminal liability of individuals acting for the corporation.

29 John C. Coffee Jr. (n 22).

30 Streteanu \& Chirita (n 17).
} 
fruitfully used by the challengers of corporate criminal liability ${ }^{31}$. Majority of the debaters have agreed upon that the private entities should be brought under the ambit of criminal liability $^{32}$. Just because there is non-marketable behaviour among the associations it does not mean that they will be exempted from criminal liability ${ }^{33}$. Therefore, no matter whether the private entity has a marketable or a non-marketable behaviour, it should be held equally liable under the criminal law. As a result, associations, foundations, parties and unions are criminally liable ${ }^{34}$ because the property or the assets they own could be used for illegal purposes as well. Not only this, but even the information they receive from their members can also be used in an illegal manner ${ }^{35}$.

In 1922, the United States Supreme Court decided that trade unions could be held criminally liable. The Supreme Court held in United Mine Workers v. Coronado Coal Co ${ }^{36}$ that since trade unions can also infringe the provisions laid down in the criminal law, they cannot be excluded from the ambit of the application of the law.

Even in common law system ${ }^{37}$, the registered and unregistered firms are treated on an equal scale and both of them are liable in the same manner ${ }^{38}$.

\section{What crimes?}

There are basically three principles for determining the crimes for which the corporations can be held liable.

The first principle talks about the general or plenary liability which implies that the juristic person's liability is same as that of an individual as corporations being practically capable of committing crime ${ }^{39}$. This principle has been taken up by England, Netherlands ${ }^{40}$, Belgium, Canada and Australia. In England, the corporations are liable for every kind of

31 Gregory L. Diskant, 'Time To Rethink Corporate Criminal Liability' (2007) New York Law Journal <http://www.pbwt.com/files/Publication> accessed 22 January 2013.

32 Joan McPhee, 'The Survival Dilemma'(21 July 2008) National Law Journal http://www.ropesgray.com/ files/Publication>, accessed on 18 February 2013; Mark Robeck, Amy Vasquez \& Michael E. Clark, 'Corporate Cooperation in the Face of Government Investigations' (May 2005)17 The Health Lawyer.

33 Luca Enriques, 'Bad Apples, Bad Oranges: A Comment from Old Europe on Post-Enron Corporate Governance Reforms' (2003) 38 Wake Forest Law Review, 911. The paper notes the recent developments in European countries in the context of corporate criminal liability.

34 Kathleen F. Brickey, 'Corporate Criminal Accountability: A Brief History and an Observation' (1982) 60 Washington University Law Quarterly, 393.

35 Streteanu and Chirita (n 19).

36 United Mine Workers v. Coronado Coal Co 269 SC 259, 344 (the US, 1922).

37 Gunter Heine (n 27).

38 Parker, 'Criminal Sentencing Policy for Organizations: The Unifying Approach of Optimal Penalties' (1989) 26 American Criminal Law Review, 513.

39 John T. Byam, 'The Economic Inefficiency of Corporate Criminal Liability' (1982) 73 Journal of Criminal Law and Criminology, 582.

40 See Stewart Field \& NicoJörg, 'Corporate Liability and Manslaughter: Should We Be Going Dutch?' (1991) Criminal Law Review, 156. 
crime $^{41}$. Though, the rule is of general liability, there are certain restrictions on it based on the principle of lex non cogit ad impossibilia ${ }^{42}$.

The second principle necessitates that the legislator discuss upon every crime, examining whether corporate criminal liability is possible or not. This very principle is being opted by France $^{43}$. Article 121-122 clearly specifies that juristic persons are liable only when the law expressly provides for such liability. This means that if a person is keen to know whether the corporation is liable for a crime, he/she needs to refer to the code and check whether the legislation has expressly provided the criminal liability of the corporation for that particular crime.

The third principle is reflected by the American law. The U.S. punishing guiding principles $^{44}$ lays down a complete list of the crimes ${ }^{45}$ or unlawful activities that can be committed by a corporation ${ }^{46}$. Criminal liability of corporations includes all those crimes as well as those which can be committed by an individual ${ }^{47}$. This means that a corporate can be held liable for theft, forgery ${ }^{48}$, bribery ${ }^{49}$ and manslaughter or negligent homicide ${ }^{50}$. Also, in People v. O'Neil, despite the fact that the corporation was not found guilty, the court observed that the corporations can be held criminally liable for even murder ${ }^{51}$.

While countries like Nepal did not opt for a system which makes a corporation liable for the commission of any criminal offence. It does not follow the principle of Respondeat Superior and still makes the director and the officials of the company liable for any crime committed in the course of their employment.

\section{When and Which Natural Persons can Attract Corporate Criminal Liability?}

When it comes to the component of mens rea of a criminal transgression ${ }^{52}$, it does not belong to the corporation but to the individual who took decision on behalf of the corporation towards that specific course of action ${ }^{53}$. This implies that the corporation would

41 Jensen \& Meckling, 'Theory of the Firm: Managerial Behavior, Agency Costs and Ownership Structure' (1976) 3 Journal in Financial Economics, 305.

42 The law cannot foresee the impossible. Streteanu \& Chirita (n 17) 112-113.

43 France amended its Code in 1991 to make corporate criminal liability more easily available. See Coffee (n 29) in WilfridJeandidier, Droit Penal General (2 ${ }^{\text {nd }}$ edn, 1991) 341-349.

44 Timothy A. Johnson, 'Sentencing Organizations after Booker' (2006) 116 Yale Law Journal, 632.

45 Parker \& Block, 'The Sentencing Commission, P.M. (Post-Mistretta): Sunshine or Sunset?' (1989) 27 American Criminal Law Review, 231.

46 See generally US Sentencing Guidelines Manual (the US 2005).

47 E.M. Wise, Criminal Liability of Corporations- USA, Criminal Liability of Corporations: La Criminalisation Du Comportement Collectif (Kluwer Law International 1996) 383- 384.

48 State v. Christy Pontiac-GMC, Inc. 354 N W 2d 17 (Minn., 1984).

49 Commonwealth v. Beneficial Fin. Co. 275 N E 2d 33 (Mass., 1971).

50 Granite Construction Co. v. Superior Ct. 149 Cal App 3d 465 (Cal App, 1983); Vaughan \& Sons, Inc. v. State 737 S W 2d 805 (Tex. Crim. App.,1987).

51 People v. O’Neil 550 N E 2d 1090 (Ill.App, 1990).

52 Gerhard O.W. Mueller, 'Mens Rea and the Corporation: A Study of the Model Penal Code Position on Corporate Criminal Liability’ (1957) 19 University of Pittsburgh Law Review, 21.

53 Streteanu \& Chirita (n 19). 
be punished without having any fault, which is clearly against the principles of the criminal law ${ }^{54}$. Although, some critics argued that since the corporations does not have the capacity to act on its own therefore, the element of actus reus cannot be applied to them ${ }^{55}$. Therefore, imposing criminal liability on a corporation for an act done by its employee on behalf of the corporation necessitates is resorting to the principle of respondeat superior ${ }^{56}$. Hence, the capacity of a corporation to act does not implies the liability ${ }^{57}$ for an act done by another, it simply means that corporations are liable for the acts done by its own employees $^{58}$ on behalf of the corporation using the authority that has been bestowed upon them by the corporations' by laws ${ }^{59}$. Moreover, those which are subject to legal duties, can not only execute those duties, but can also infringe them ${ }^{60}$. But if the employee's act was solely for his own benefit or the benefit the third party, then the corporation will not be held liable except for the strict liability offenses ${ }^{61}$. However, a good defence ${ }^{62}$ for the corporations will be that, the corporations can show that the managers used due attentiveness while attempting for the prevention of the crime ${ }^{63}$.

\section{Sanctions}

The debatably distinctive sanctioning attribute of criminal liability is the criminal sanction's potentially stigmatizing effect ${ }^{64}$. Mainly four types of sanctions are discussed below. These are

- Legally Imposed Sanctions

- Social Sanctions.

- Remedial Sanctions.

54 H.J. Hirsch, La Criminalisation du ComportamentCollectif - Allemange, Criminal Liability of Corporations: La Criminalisation Du Comportement Collectif (Kluwer Law International 1996) 31.

55 Ferguson v. Wilson 2 LR. Ch App 77 (CA, 1866).

56 Fisse (n 11).

57 Reinier H. Kraakman, 'Corporate Liability Strategies and the Costs of Legal Controls' (1984) 93, Yale Law Journal, 857.

58 Andrew Weissmann \& David Newman, 'Rethinking Criminal Corporate Liability' (2007) 82 Indiana Law Journal, 411; George Ellard, 'Making the Silent Speak and the Informed Wary'(2005) 42 American Criminal Law Review, 985.

59 Streteanu \& Chirita (n 19).

60 Hirsch (n 27).

61 Guy Stessens, 'Corporate Criminal Liability: A Comparative Perspective' (1994) 43 International and Comparative Law Quarterly, 493.

62 Eli Lederman, 'Models for Imposing Corporate Criminal Liability: From Adaptation and Imitation Toward Aggregation and the Search for Self-Identity' (2000) 4 Buffalo Criminal Law Review, 694.

63 Robert E. Lane, 'Why Businessmen Violate the Law' (1953) 44 Journal of Criminal Law, Criminology and Police Science, 151.

64 Mark A. Cohen, 'Corporate Crime and Punishment: An Update on Sentencing Practice in the Federal Courts' (1991) 71 Boston University Law Review, 247; Jonathan M. Karpoff \& John R. Lott Jr., 'The Reputational Penalty Firms Bear from Committing Criminal Fraud' (1993) 36 Journal of Law \& Economics, 757. 
- Economic Sanctions.

These sanctions have been formulated in a way that these may create deterrence ${ }^{65}$ which is the ultimate objective of penal laws.

\section{Legally Imposed Sanctions}

'Nothing is worse than a static legislature and a mute judiciary.'

Legislatures authorize judges and governmental agencies to inflict many sanctions in corporate criminal proceedings, including cash fines, probation ${ }^{66}$, debarment ${ }^{67}$, loss of license $^{68}$ and other related penalties ${ }^{69}$. Non pecuniary penalties, such as imprisonment, are not applicable in the corporate context. Usually, cash fines are most favourable. The reason for this hierarchy of sanctions is that the fine is easier to bear for the corporations than other legally imposed sanctions ${ }^{70}$. Critics argue that cash fines have an indirect effect on the stockholders of the corporation and also on a number of guiltless employees who are working for the corporation who would lose their income ${ }^{71}$. In the critics' view, this is unacceptable as even the innocent individuals will fall under its ambit. ${ }^{72}$

If the defendant corporation cannot pay the entire amount as imposed by the court of law, the fine imposed will not be enough to conceive optimal deterrence ${ }^{73}$. In such a case, to obtain optimal deterrence ${ }^{74}$, the court may impose further sanctions like cancellation of license, prohibition on advertising or selling on specific markets ${ }^{75}$ and so on. This combined penalty will have a stronger deterrent impact ${ }^{76}$. However, probation will only be desirable if there is a need to improve the internal structure of the corporation ${ }^{77}$.

65 Toni Makkai and John Braithwaite, 'The Dialectics of Corporate Deterrence'(1994) 31 Journal of Research in Crime and Delinquency, 347.

66 John C. Coffee, Jr., Richard Gruner \& Christopher D. Stone, 'Standards for Organizational Probation: A Proposal to the United States Sentencing Commission' (1988) 10 Whittier Law Review, 77.

67 Harvey L. Pitt \& Karl A. Groskaufmanis, 'Minimizing Corporate Civil and Criminal Liability: A Second Look at Corporate Codes of Conduct' (1990) 78, The Georgetown Law Journal, 1559.

68 Sara Sun Beale \& Adam G. Safwat, 'What Developments in Western Europe Tell Us About American Critiques of Corporate Criminal Liability’ (2004) 8 Buffalo Criminal Law Review, 89.

69 Gary S. Becker, 'Crime and Punishment: An Economic Approach' (1968) 76 Journal of Political Economy, 169 .

70 A. Mitchell Polinsky\& Steven Shavell, 'The Optimal Use of Fines and Imprisonment' (1984) 24 Journal of Public Economies, 89.

71 James Gobert, 'Controlling Corporate Criminality: Penal Sanctions and Beyond' (1998) Web Journal of Current Legal Issues <http://webjcli.ncl.ac.uk/1998/issue2/gobert2.html>, accessed 18 February 2013.

72 Streteanu \& Chirita (n 19).

73 Ibid.

74 See Wayne R. Lafave \& Austin W. Scott Jr., Criminal Law (2 $2^{\text {nd }}$ edn, West Pub Co 1986).

75 Jonathan R. Macey, 'Agency Theory and the Criminal Liability of Organizations' (1991) 71 Boston University Law Review, 315.

76 Coffee (n 29).

77 See Arthur R. Miller \& Michael H. Davis, Intellectual Property Patents, Trademarks, and Copyright In A Nutshell, (2 ${ }^{\text {nd }}$ edn, Thomson West 1990). 


\section{Concept of Secondary Liability}

'A living person has a mind which can have knowledge or intention and he has hands to carry out his intention. A corporation has none of these; it must act through living persons. ${ }^{78}$

A company being an artificial legal person is incapable of doing any act by itself and whatever act is done is done by natural person acting on behalf of the company. So even if the person was acting within the course of employment should not matter and the person must be punished with strict liability. Since the corporation cannot be imprisoned, so only fine can be imposed to it as a means of punishment, but the natural person acting on behalf of the company who ordered the commission of the offence or who was in a position to influence the activity of the company for the commission of such offence must be punished with imprisonment. The secondary liability is necessary so that directors or any such person who ordered the commission of such offence or actively or inactively participated in the commission of such offence cannot easily escape the liability by shifting the liability on the company which is incapable of acting on its own.

Directors are bound to use fair and reasonable diligence in discharging the duties, to act honestly and with such care as is reasonably expected from them, having regard to their knowledge and experience ${ }^{79}$. In a particular case ${ }^{80}$ it was held that 'A director will be personally liable on a company contract when [he/she] has accepted personal liability either expressly or impliedly. Directors are the agents or the trustees of a Company.'

In Moriarty v. Regent's Garage \& Engg Co ${ }^{81}$, Lush J. opined that 'a director is not a servant of any master. [He/she] cannot be described as a servant of the company or of anyone'. In the same case, Mc Cardie LJ delivered the opinion that 'A director is in fact a director or controller of the company's affairs. [He/she] is not a servant. ${ }^{82}$

The directors of a company must discharge their duties and obligations with skill and diligence as expected from a reasonable person of their knowledge and experience ${ }^{83}$. A director must display care in performance of work assigned to one. ${ }^{84}$ Any provision in the company's articles or in any agreement that excludes the liability of the directors for negligence ${ }^{85}$, default ${ }^{86}$, misfeasance ${ }^{87}$, breach of duty ${ }^{88}$ or breach of trust ${ }^{89}$, is void. The

\footnotetext{
78 Haldane LC in Lennard's Carrying Co.v. Asiatic Petroleum Co. AC 705 (the US, 1915).

79 Norval Morris, 'The Interplay Between Corporate Liability and The Liability of Corporate Officers' (1981) 1 Northern Illinois University Law Review, 36.

$80 \quad$ R.K. Dalmia et al v. The Delhi Administration 1 SCR 253 (India, 1963).

81 Moriarty v. Regent's Garage \&Engg Co. [1921] 1 KB 423.

82 Ibid 446

83 Arthur W. Machen, 'Corporate Personality' (1911) 24 Harvard Law Review, 253.

84 Kenneth Mann, Stanton Wheeler \& Austin Sarat, 'Sentencing the White-Collar Offender' (1980) 17 American Criminal Law Review, 479.

85 Ronald J. Maurer, Comment, 'The Federal Sentencing Guidelines for Organizations: How Do They Work and What Are They Supposed to Do?' (1993) 18 University of Dayton Law Review, 799.
} 
company cannot even indemnify the directors against such liability ${ }^{90}$.Therefore, the concept of secondary liability must be introduced by the legislature which will not only meet the ends of justice but will not also let the offender escape the liability.

Some provisions in the Indian Penal Code also need strict amendments in order to make sentencing policy, just as there are some provisions in the Indian Penal Code that do not include fine and just imprisonment as the sole mode of punishing the offender ${ }^{91}$. Not only this, but the fines prescribed in the Indian Penal Code hardly affect the offender as the amount of fines is too less to affect a prosperous body. Moreover, sections. 45, 63, 68, 70(5), 203, among others, of the Indian Companies Act lay down the provisions for punishing the officials of the company only and not the corporation itself. These provisions are handicapping the Indian courts while punishing the corporate bodies.

The legislature needs to increase the scope of the corporate crimes and the punishments there upon. Acts like money laundering ${ }^{92}$, terrorist financing ${ }^{93}$, tax evasion, submission of securities reports containing false information, market manipulation and insider trading ought to be recognized as corporate crimes keeping in mind the very purpose of law, as the law sends an emblematic message, that no crime goes unpunished. Apart from that, the issue of corporate killing needs to be addressed ${ }^{94}$.

\section{Social Sanctions}

Both the society and the legal system impose sanctions ${ }^{95}$ on the corporations, as described below:

86 Seth Maxwell, 'The Foreign Corrupt Practices Act and Other Arguments against a Due Diligence Defence to Corporate Criminal Liability' (1982) 29 University of California at Los Angeles Law Review, 447.

87 John B. McAdams, 'The Appropriate Sanctions for Corporate Criminal Liability: An Eclectic Alternative' (1977) 46 University of Cincinnati Law Review, 989.

88 James McConvill and MirkoBagaric, 'Criminal responsibility based on complicity among corporate officers' (2004)16 Australian Journal of Corporate Law, 172.

89 Alan C. Michaels, 'Fastow and Arthur Andersen: Some Reflections on Corporate Criminality, Victim Status, and Retribution' (2004) Ohio State Journal of Criminal Law

〈http://moritzlaw.osu.edu/osjcl/issue2_articles/Michaels.pdf〉, accessed 5 March 2013.

$90 \quad$ Dorchester Finance Co. Ltd. v. Stebbing [1989] BCLC 498.

91 AngiraSinghvi, 'Corporate Crime and Sentencing in India: Required Amendments in Law' (2006) 1 International Journal of Criminal Justice Sciences < http://www.sascv.org/ijcjs/angira.pdf>, accessed 14 January 2013.

92 Michael J. Lynch, Danielle McGurrin \&Melissa Fenwick, 'Disappearing act: The representation of corporate crime research in criminological literature' (2004) 32 Journal of Criminal Justice, 389.

93 Samuel R. Miller and Lawrence C. Levine, 'Recent Developments in Corporate Criminal Liability' (1984) 24 Santa Clara Law Review, 41.

94 Charles G. Little, 'Punishment of a Corporation - The Standard Oil Case' (1905) 3 Illinois Law Review, 446.

95 Miriam Miquelon, 'Dispositions in Criminal Prosecutions of Business Organizations' (2003) 51 The United States Attorneys Bulletin 〈http://www.usdoj.gov/usao/eousa/foia_reading_room/usab5103.pdf> accessed 1 January 2013. 
a. Reputational loss in the corporate context: Reputational loss ${ }^{96}$ in the corporate context strictly refers to the unwillingness of the employees and the customers to deal with the corporation in future ${ }^{97}$. Even the managers feel ashamed about the conviction of their corporation ${ }^{98}$.

b. Socially desirable use of reputational penalties: The reputational penalty ${ }^{99}$ which the market imposes can be influenced by the government. Suppose that reputational sanctions ${ }^{100}$ and cash fines are usually, although not faultlessly, replaceable by the way of promising better class of products and services ${ }^{101}$.

c. The courts may also ask the corporations to publish their crime widely in the media specified by the court ${ }^{102}$. This may be made a compulsory provision as a mode of social sanction and the corporation must fund the publication as well. The publication should not just include the nature of the offence committed and the punishment received thereof, but shall also publicize the steps that will be taken by the company in future in order to prevent the recurrence of such events ${ }^{103}$. This sanction is necessary for the reason that it will not only affect the good will of the corporation but adversely affect the market reputation of the company as well which will result in very less or no customers.

\section{Remedial Sanctions}

While determining the appropriate standard of punishment applicable to a company, the effects it could have on innocent parties have to be borne in mind.

Victim oriented approach: An innocent person falling prey of corporate crime must be given full assistance. Crimes like corporate killings and rape by the corporate officials must be given appropriate compensation and the aim should not be just to penalize the company but to rehabilitate the victim as well.

Rehabilitation of the victims is one of the ways of imposing liability on the corporation. It could be to rehabilitate the victim such as in case of corporate killing, if the sole earning

96 John P. Minkes \& A.L Minkes, 'The criminology of the corporation' (2000) 26 Journal of General Management, 1 .

97 'Developments in the Law - Corporate Crime: Regulating Corporate Behaviour through Criminal Sanctions'(1979) 92 Harvard Law Review, 1227.

98 David Charny, 'Non legal Sanctions in Commercial Relationships' (1990) 104 Harvard Law Reviews, 373.

99 Richard A. Posner, Economic Analysis of Law (8 $8^{\text {th }}$ edn, Aspen Publishers 2010).

100 Cohen, Ho, Jones \& Schleich, 'Organizations as Defendants in Federal Court: A Preliminary Analysis of Prosecutions, Convictions and Sanctions, 1984-1987' (1988) 10 Whittier Law Review, 103.

101 Jonathan M. Karpoff \& John R. Lott, Jr., 'The Reputational Penalty Firms Bear from Committing Criminal Fraud'(1993) 36 Journal of Law \& Economics, 757.

102 See National Common Reform Of The Federal Criminal Laws, Study Draft Of A New Federal Criminal Code (National Common Reform Of The Federal Criminal Laws 1970)

103 Andrew Cowan, 'Scarlet Letters for Corporations? Punishment by Publicity Under the New Sentencing Guidelines’ (1992) 65 Southern California Law Review, 2387. 
member of a family is killed, the corporate should give employment to any other member of the same family in the corporation as per the qualification of the member. The main aim in dealing with such crimes should not be just to punish the offender but also to rehabilitate the victim as a mode of compensation to the victim and the cost incurred during the rehabilitation of the victim shall be covered by the corporation only.

\section{Proposed Legislative Amendments}

The legislations of the following two countries need some amendments so as to create a better mechanism to regulate corporate criminal liability.

\section{India:}

In India, for the imposition of corporate criminal liability, that may act as deterrent for corporations there is an urgent need of amendment in some of the statutory provisions such as cection 357 of Code of Criminal Procedure 1973 as it is subjected to several limitations which needs to be amended. The object of the same is being forgotten by the Indian courts and the provisions thereof are seldom invoked by the courts.

The Supreme Court of India while discussing the scope and object of section 357 of the Code of Criminal Procedure in Hari Kishan and State of Haryana V. Sukhbir Singh ${ }^{104}$ observed that 'It is an important provision but the courts have seldom invoked it, perhaps due to the object of it.'

This section empowers the courts to award compensation to the victims while passing judgment or conviction. During conviction, the court may order accused to pay compensation to the victim. This power was intended to do something to re assure that the victim is not forgotten in the criminal justice system. However Section 357 (1) is subject to certain limitations as may be stated below:

a. Compensation can be ordered only out of fine realized and if no fine is realized, compensation to victim cannot be directed to be realized.

b. In very rare cases under the Indian Penal Code, the maximum amount of fine is imposed. Moreover maximum fine as prescribed in Indian Penal Code about 150 years back is inadequate in terms of real losses to victims.

c. Quantum of compensation either is limited to the fine levied and not in addition to it or exceeds the fine imposed.

The right to compensation has also been recognized by the Supreme Court as an integral part of right to life and liberty under article 21 of the Indian constitution ${ }^{105}$.

\footnotetext{
104 HariKishan and State of Haryana V. Sukhbir Singh AIR 1988 SC, 2127 (India).

105 Rudul Sahvs State of Bihar AIR, 1983 SC, 1086 (India).
} 
The above shortcomings of Section 357 of the Code of Criminal Procedure must be covered by the legislature as it will help courts to act in a specific direction while awarding compensation to the victims of the corporate crimes. Moreover, if the above mentioned limitations are overcome by the legislature, the same would lend a hand to the injured party, as the corporations have the capacity to provide huge compensation to the victims of the corporate crimes. So the courts must always take into consideration the financial capacity of the offender while awarding compensation to the victims of the crime.

\section{Nepal}

In Nepal, there is no tangible mechanism to punish corporate crime. Section 23 of the PCA provides for conviction of company's officials who are in the position of taking decision at the time of commission of offense but it does not provide for making the company liable for the offense of bribery. Apart from this, there is no settled principle in Nepal as regards to the concept as to whether legal persons can commit an offense as it acts through its officers and is unable to take any decisions on its own. Furthermore, there is a blurred picture of imposition of liability on legal persons under section 23 of the PCA when the principal official of one company bribes for the benefit of another company within the same conglomerate liability of legal persons for bribery.

In Nepal, the Companies Act ${ }^{106}$, provides for imposition of liability for different directors, auditors and employees. Apart from this, the Act also provides for imposition of criminal liability on corporate under section $160(\mathrm{o}),(\mathrm{p}),(\mathrm{r}),(\mathrm{w}),(\mathrm{x})$, section 161(g) and section 162 , but the courts in Nepal are still reluctant to impose criminal liability on corporations. Uncertainty prevails as to whether a company can be convicted for such offences where the punishment prescribed by the statute is imprisonment and a fine. In Nepal, only secondary liability i.e. the liability of principal officials and partners of the firm is recognized.

But there is an urgent need of amendment in sections 160 and 161 of the Companies Act 2006 of Nepal as it provides for the imposition of maximum fine of rupees fifty thousand on company's officials or the company itself. But the amount of fine is not sufficient enough to deter and prevent commission of such crimes. Apart from this, section162 of the Act imposes maximum fine to the limit of twenty thousand. Imposition of the titular amount of fine is not going to help in achieving the objective of prevention of corporate crimes. Thu, there is a need to increase the fine to such an amount that may alarm the offenders.

In order to tackle these challenges, it is necessary that criminal liability is also imposed on corporations so that actual justice can be served to the victims of the crime. It is clear that there is need of amendment in the legislation regulating corporate crime.

\section{Economic Sanction}

106 The Company Act (Nepal) 2006. 
Exemplary damages: Mere imposition of nominal fines would not serve the purpose. The aim of the imposition of fines must make it act as deterrence for the corporation. Although, for big corporations it is quite easy to use their big bank balances to escape the punishment of fine very easily, but if the fine imposed is exemplary then it will definitely not be that easy for even the larger firms to escape the liability as it will heavily affect the financial position of the company.

Forfeiture of assets: Forfeiture of assets could be another way of imposing liability on the company. If all the assets of the company are seized it will greatly affect the working of the corporation and can even lead to the shutdown of company.

Temporary shutdown: If a company is found to be committing certain offence repeatedly, the courts must order temporary shutdown of the company without any warning such as in case of food adulteration where it is found that the company is continuously performing such activities. This will not only impede such activities of corporation but also prevent mishaps and losses to the innocent victims.

Permanent Closure of the Company: In cases where the intensity of the offence committed by the corporation is very high, for instance, in cases of corporate killings, food adulteration and intentional gross carelessness of the company have resulted in the loss of several lives of the innocent public, permanent closure can be the most suiting punishment. This can be a situation, where a fraudulent act took place but the management or the board decided not to take any action towards the same.

\section{Conclusion}

Writing about American corporate criminal liability regime, Gerhard Mueller rather famously noted, 'Nobody bred it, nobody cultivated it, nobody planted it. It just grew. ${ }^{, 107}$ Mueller's quip, however clever, is neither unique in a field since many scholars and practitioners have decried it as unprincipled and under-theorized, ${ }^{108}$ nor, more important, entirely accurate. To conclude the purpose of corporate criminal liability, we must comprehend that it is only one of a number of diverse liability approaches that can control behaviour in and around corporations. It may be asserted that the entire evolution of the criminal liability of corporation all around the world has been from darkness to radiance; the evolution has been appreciable with considerable shifts in attitude and approach. Despite the degree of managerial error entailed in the crimes, crimes commenced for corporate advantage by recruits and other corporate agents often fabricate corporate

107 Gerhard O.W. Mueller, 'Mens Rea and the Corporation: A Study of the Model Penal Code Position on Corporate Criminal Liability' (1957) 19 University of Pittsburgh Law Review, 21.

108 Amanda Pinto \& Martin Evans, Corporate Criminal Liability (3 ${ }^{\text {rd }}$ edn, Sweet \& Maxwell 2003) 3-17; V.S. Khanna, 'Corporate Criminal Liability: What Purpose Does It Serve?' (1996) 109 Harvard Law Review, 1477. 
profits, predominantly when those crimes go hidden and with impunity. And a just punishment embraces the ethical condemnation of the society. Instead of serving just as a sheer supplement to corporate fines, ground breaking corporate sentences shall be the key objectives of corporate criminal prosecutions. The emergence and growth of the concept of corporate criminal liability in different parts of the world has been of great significance and the landmark judgments on the same in countries US and India make it evident that corporations can be prosecuted for the commission of offences committed by its employees, managers or directors. It is the need of the hour that countries like Nepal, Germany and Brazil be in sync with the legal advancement in the context of interpretation and implementation of law concerning corporate criminal liability. A fragmented piecemeal approach is not enough. The concept of corporate criminal liability was not viewed by every legal system in the same way. This divergence about how to treat so-called legal persons resulted in an obvious consequence of uneven playing field. But now this uneven playing field seems to be getting levelled as most of the counties now recognize corporate criminal liability which gives a solution to the question of conflicting liable making it clear that corporate can be held liable for crimes. However, corporate criminal liability is only in its inception stage and this makes the area available for constant review and up gradation. Lastly, the authors firmly believe that it is necessary to slot in different forms of punishment through necessary amendments and serious strides are called for at the earliest in order to put off the corporations from indulging into corporate misconduct.

$* * * * * * * * * * * * * * * * * * *$ 